Lidia Lewicka

Szczecin

\title{
Troska o fachowe przygotowanie zawodowe pracowników bibliotek w życiu i działalności Alodii Kaweckiej-Gryczowej i Józefa Grycza
}

Idea kształcenia pracowników bibliotek na poziomie akademickim sięga w naszym kraju czasów Komisji Edukacji Narodowej. Zanim jednak utworzono Komisję Edukacji Narodowej całokształt spraw dotyczących bibliotekarstwa w Polsce, z organizacją bibliotek i ich bytem materialnym włącznie, nie wchodził w orbitę zainteresowań organów władzy ${ }^{1}$. Wprowadzone przez Komisję Edukacji Narodowej uregulowania prawne dały początek pierwszej w Polsce sieci bibliotecznej ${ }^{2}$. Zdobycze powyższych reform przetrwały w świadomości wielu szlachetnych, światłych ludzi mimo kolejnych rozbiorów Polski, zawieszenia działalności Komisji Edukacji Narodowej w 1794 roku i utraty zbiorów Biblioteki Załuskich, które w 1795 roku wywieziono do Rosji ${ }^{3}$. Dyrektywę Komisji

1 „Biblioteki klasztorne, szkolne i akademickie żyły własnym, zamkniętym życiem, zdane tylko na siebie w utrzymaniu, pomnażaniu i opracowywaniu zbiorów, z przypadkową kadrą pracowników bibliotecznych. Pozbawione często najprostszych form organizacyjnych były niekiedy składnicami książek, a nie bibliotekami we właściwym tego słowa znaczeniu” (Z. Gaca-Dąbrowska, Bibliotekarstwo II Rzeczypospolitej, Warszawa 2007, s. 15); dopiero w dziele reformy szkolnictwa, podjętym przez Komisję Edukacji Narodowej, bibliotekarstwo wciągnięto w ogólny system oświaty. Opracowano szeroko zakrojony program ujęcia w jednolitą całość ogółu istniejących na terenie Polski bibliotek i podporządkowania ich polityce państwowej.

${ }^{2}$ Sieć ta składała się z Publicznej Biblioteki Rzeczypospolitej Załuskich, książnic obu szkół głównych: koronnej (Uniwersytetu Krakowskiego) i Wielkiego Księstwa Litewskiego (Akademii Wileńskiej) oraz licznych bibliotek wszystkich rodzajów szkół niższego poziomu. „Sieć ta podlegała jednolitemu zwierzchnictwu i przepisom, które regulowały organizację bibliotek, ich działalność, zapewniały odpowiednie lokale, środki na utrzymanie a także fachowych pracowników bibliotecznych. Zawód bibliotekarza został wówczas postawiony wysoko i w wymaganiach (wykształcenie ogólne, kwalifikacje fachowe, zadania społeczne) i w uznaniu jego rangi (zrównanie w stopniach i zasługach z innymi profesorami)" - Z. Gaca-Dąbrowska, dz. cyt., s. 16.

${ }^{3}$ Politykę oświatową Komisji Edukacji Narodowej i jej wytyczne w sprawach bibliotecznych realizowały po kolejnych rozbiorach: w Księstwie Warszawskim utworzona 
Edukacji Narodowej w zakresie akademickiego nauczania bibliotekarzy wcielał w życie m.in. Joachim Lelewel, zastępca profesora bibliografii na Uniwersytecie Warszawskim w latach 1821-18244.

Po okresie zahamowania rozwoju kultury polskiej, a tym samym rozwoju bibliotek, żywszą działalność w zakresie bibliotekarstwa podjęło dopiero kolejne pokolenie ideowych spadkobierców Komisji Edukacji Narodowej w drugiej połowie XIX wieku. W odpowiedzi na politykę władz zaborczych, w kraju i poza jego granicami, zaczęły licznie powstawać biblioteki fundacyjne ${ }^{5}$. Pozycjami książkowymi z prywatnych zbiorów społeczeństwo zasilało także księgozbiory bibliotek uniwersyteckich w Krakowie, Lwowie, Wilnie i Warszawie. Wspomniane powyżej książnice „stawiały sobie za cel główny ustrzeżenie przed rozproszeniem zabytków piśmiennictwa narodowego i gromadzenie zbiorów dla przyszłych pokoleń w odrodzonym już państwie. Stawały się oparciem dla bieżących badań naukowych, a niekiedy także azylem dla ludzi nauki, którzy podejmując w nich obowiązki bibliotekarzy, szukali tu, z braku innych możliwości, warunków do prowadzenia własnych prac badawczych czy chociażby koniecznych dla egzystencji środków materialnych"6.

Na przełomie XIX i XX wieku dość mocno zarysował się w bibliotekarstwie polskim podział na bibliotekarstwo naukowe i oświatowe. Kadra bibliotek naukowych (uniwersyteckich, fundacyjnych, prywatnych) rekrutowała się niemal wyłącznie z grona profesorów uniwersyteckich, pisarzy, literatów, uczonych różnych specjalności, a nowy narybek terminował u boku mistrzów. Licznie powstające od lat osiemdziesiątych XIX wieku biblioteki powszechne, tzw. oświatowe, rozrzucone po całym kra-

w 1807 r. Izba Edukacyjna, przekształcona w 1812 r. w Dyrekcję Edukacji Narodowej, natomiast w powstałym w 1815 r. królestwie kongresowym - Ministerstwo Wyznań Religijnych i Oświecenia Publicznego. Oba te organy kierowane były przez byłego członka Towarzystwa do Ksiąg Elementarnych - Stanisława Kostkę Potockiego, mecenasa sztuki, kolekcjonera i bibliofila. Przy pomocy swych kolegów i współpracowników realizował on założenia polityki bibliotecznej, nakreślone przez KEN. Wśród licznych spraw wysuwano również kwestię odpowiedniego doboru kadry bibliotecznej i jej przygotowania zawodowego.

${ }^{4}$ J. Lelewel prowadził kurs bibliografii (w dzisiejszym rozumieniu - bibliotekoznawstwa) na Wydziale Sztuk Pięknych UW. Jego dzieło Bibliograficznych ksiag dwoje uważane jest za pierwszy polski podręcznik bibliotekarski. Lelewel nadawał bibliotekarzowi rangę wychowawcy i współtwórcy nauki.

${ }_{5}^{5}$ Wymienić tu należy m.in. biblioteki: Ossolińskich we Lwowie (1817), Czartoryskich w Krakowie, Działyńskich w Kórniku (1826), Raczyńskich w Poznaniu (1829), Zamoyskich (przewieziona do Warszawy w 1811 r.) i Krasińskich (1844) w Warszawie, oraz Bibliotekę Polską w Paryżu (1838), Bibliotekę Wersalską, Bibliotekę Szkoły Polskiej w Batignolles (1842) czy Muzeum w Raperswilu.

${ }^{6}$ Z. Gaca-Dąbrowska, dz. cyt., s. 17. 
ju, często w dużym oddaleniu od centrów intelektualnych, obsługiwane były przez ludzi dobrej woli, nauczycieli ludowych i społeczników-entuzjastów bez przygotowania zawodowego ${ }^{7}$. „Organizowano kursy szkoleniowe, które uczyły nie tylko techniki pracy bibliotekarskiej, lecz zmierzały również, pomimo znacznych różnic orientacji politycznych, postaw społecznych i ideologicznych - do wychowania bibliotekarza oświatowca, społecznika i patrioty. Taki typ pracownika bibliotecznego odpowiadał bowiem potrzebom bibliotek, które pełniły w czasach niewoli ważną funkcję społeczną, współuczestnicząc w kształtowaniu samowiedzy i integracji narodowej" 8 .

Rzeczpospolita Polska doczekała swego odrodzenia w 1918 roku. Na lata 1918-1939 przypada okres bujnego rozkwitu bibliotekarstwa polskiego, obfitujący w wybitne indywidualności twórcze i talenty naukowe. Odnotować można w tym czasie doniosłe wydarzenia prowadzące do unowocześnienia i rozwinięcia bibliotek, służących pracy naukowej i pełniących rolę społeczno-oświatową. Z perspektywy lat i przez pryzmat dorobku piśmienniczo-naukowego, nie sposób nie uznać za postaci wybitne, ukształtowanych przez epokę II Rzeczpospolitej, Alodii Kaweckiej-Gryczowej i Józefa Grycza. „Krąg nauki jest naturalnym otoczeniem bibliotekarzy, podobnie jak biblioteka - nieodzownym zapleczem uczonych. Oba światy, nauki i bibliotek, stanowią wzajemnie przenikające się i wzbogacające sfery oddziaływania. Dzięki temu znakomite rezultaty zawodowe osiągają te osobistości, które czynne są równocześnie na polu praktyki bibliotekarskiej i badań naukowych. One też, otoczone szacunkiem i sympatią, kreują godne naśladowania wzorce osobowe". Słowa te, nakreślone przez Barbarę Bieńkowską w przedmowie do książki $W$ kręgu nauki i bibliotek, mogą śmiało posłużyć jako synteza treści, którymi wypełnione było życie osobiste i zawodowe państwa Alodii Kaweckiej-Gryczowej i Józefa Grycza9 .

7 „Trud ich szkolenia podjęły, pół jawnie pół tajnie, placówki społeczne i oświatowe. W zaborze pruskim Towarzystwo Oświaty Ludowej, potem Towarzystwo Czytelń Ludowych, w Galicji Towarzystwo Szkoły Ludowej wspierane w tej akcji przez uniwersytety Krakowski i Lwowski oraz najpoważniejsze, postępowe i nowatorskie Towarzystwo Uniwersytetu Ludowego im. Mickiewicza w Krakowie. W Warszawie działało w tym kierunku Towarzystwo Dobroczynności ze Stanisławem Michalskim i Stefanią Sempołowską na czele" (H. Więckowska, Akademickie ksztatcenie bibliotekarzy. Zarys historyczny, Warszawa 1979, s. 17-18).

${ }^{8}$ H. Więckowska, Akademickie ksztatcenie bibliotekarzy. Zarys historyczny, Warszawa 1979, s. 18

${ }^{9}$ W kręgu nauki i bibliotek, („Bibliotekarze Polscy we Wspomnieniach Współczesnych", 3), Warszawa 1993, s. 5. 
Moje rozważania o zainteresowaniu Gryczów problemem kształcenia kadr bibliotecznych zacznę przekornie od pokazania ich stosunku do czytelnika - odbiorcy książki. „Całą działalność Grycza cechowało nastawienie frontem do czytelnika, zawsze z punktu widzenia potrzeb społecznych” - wspomina Emilia Kurdybacha ${ }^{10}$. „W 1924 r. artykułem $O$ polskie przepisy katalogowe podjął Grycz aktualną wówczas sprawę opracowania instrukcji katalogowej, ujednolicenia przepisów, które, jak się wyraził, nie do tego mają służyć, by dane dzieło bibliotekarz umiał skatalogować, lecz aby czytelnik mógł je łatwo i pewnie znaleźć w katalogu"11. Natomiast Alodia Kawecka-Gryczowa istotę relacji książka czytelnik ujęła trafnie w jednym zdaniu: „Książka uzyskuje wówczas pełnię życia, gdy treść swą przekazuje czytelnikowi" ${ }^{12}$. Potrzebne jest jednak miejsce, bądź miejsca czy instytucje, w których treść książek będzie udostępniana, a nieodzownym elementem łańcucha komunikacyjnego książka - czytelnik są pośrednicy pracujący w tychże instytucjach. Jako idealne miejsce do kontaktu czytelnika $\mathrm{z}$ książką jawi się w przekonaniu Gryczów biblioteka o różnym stopniu publiczności, w zależności od zasięgu udostępniania zbiorów, a idealny pośrednik to dobrze przygotowany do wykonywania swojego zawodu bibliotekarz. Alodia Gryczowa pięknie ujęła to, jeszcze jako początkujący bibliotekarz naukowy, pisząc w swoim referacie z 1936 roku: „Niewątpliwie najwięcej możliwości oddziaływania znajduje książka w bibliotece publicznej. Nietylko (sic!) dlatego, że tutaj jest ona dostępna każdemu, że przechodzi z rąk do rąk, że funkcje jej są zwielokrotnione. Ale i dlatego także, że tutaj znajduje ona pieczołowitego, bezinteresownego pośrednika, który, nie narzucając się, ukryty poza książką, najlepiej umie skierować na nią uwagę czytelnika"13. Wprawdzie po latach, już jako profesor z ogromnym dorobkiem naukowym, wspominając swój udział w zjeździe bibliotekarzy w 1936 ro$\mathrm{ku}$, powiedziała, że wygłoszony tam referat był wynikiem zabiegów dydaktycznych jej ówczesnych bezpośrednich przełożonych, którzy, w ramach rzucania na głęboką wodę kandydata na tzw. bibliotekarza naukowego, kazali jej opracować taki a nie inny temat. Niezmienne jednak

${ }^{10}$ E. Kurdybacha, W centrum polskiego bibliotekarstwa, czyli Józef Grycz (1890-1954), [w:] Twórcy nowoczesnego bibliotekarstwa polskiego, red. B. Kocowski, Wrocław 1974 (dalej cyt. E. Kurdybacha, W centrum...), s. 118.

11 Tamże, s. 118-119.

12 A. Kawecka-Gryczowa, Bibljotekarstwo publiczne, [w:] IV Zjazd Bibljotekarzy Polskich w Warszawie dnia 31 maja - 2 czerwca 1936 roku. Referaty, cz. 2, Warszawa 1936, s. 79.

13 Tamże, s. 79-80. 
na przestrzeni lat pozostało postrzeganie przez nią bibliotekarza jako tego, który jest niezbędnym pośrednikiem między światem książek a światem czytelników. Jej wypowiedź po latach pracy z książką i dla książki niewiele odbiega od opinii zawartej w referacie z 1936 roku. W wywiadzie z 1980 roku, którego udzieliła „Przeglądowi Bibliotecznemu”, stwierdza, iż na przestrzeni 60 lat (1919-1979), od czasów tworzenia państwa polskiego po I wojnie światowej, można wyróżnić trzy różne epoki (międzywojnie, II Wojna Światowa i okupacja, okres powojenny) w dziejach udostępniania książki w Polsce. Jednak łącznikiem wiążącym te trzy epoki jest według niej ,przede wszystkim człowiek: mądry, oddany swemu zawodowi, sprawie książki i kultury ojczystej, wierny mu w pomyślnych i tragicznych przygodach kraju, z uporem, niekiedy z entuzjazmem (jak po 1945 r.) i poświęceniem (jak w latach 1939-1945) budujący warsztaty służące oświacie i nauce społeczeństwa. A przecież wiemy, że zawód to mało efektowny, nie daje ani sławy, ani zaszczytów, ani pieniędzy"14. Pytana o najpilniejsze potrzeby bibliotek, obok troski o właściwe pomieszczenia, zaopatrzenie na dostatecznym poziomie w książki i czasopisma tak polskie jak i zagraniczne oraz w pomoce techniczne, wymieniała także potrzebę fachowej obsługi, zauważając, że jest to jeden $\mathrm{z}$ niedostatków, z którym borykają się biblioteki. Pracę nad dawną książką zawsze umiejętnie łączyła $\mathrm{z}$ troską o los książki w ogóle, także w wymiarze szczególnej troski o stan i poziom polskiego bibliotekarstwa. Wśród pozytywnych zjawisk występujących w okresie powojennym, ważne miejsce przypisywała rozbudowie systemu kształcenia bibliotekarzy. Jako jedno z miejsc zdobywania wiedzy i doskonalenia warsztatu bibliotekarzy wskazywała działy starych druków w bibliotekach, wymieniając wśród ich zadań funkcje szkoleniowe i wychowawcze. „Szkoleniowe - to znaczy przygotowanie młodej kadry specjalistów (nawet po skończonych studiach bibliotekoznawczych), organizowanie praktyk, ewentualnie wykładów popularyzatorskich dla szerszej publiczności"15. Ubolewała mocno nad brakiem odpowiedniej instytucji i wykształconej kadry, środków w postaci skór, papierów, narzędzi i preparatów niezbędnych do przeprowadzania we właściwy sposób konserwacji dokumentów papierowych i pergaminowych. Wspominając własną drogę i ścieżkę zdobywania wiedzy w zawodzie bibliotekarza Alodia Kawecka-Gryczowa mówiła:

14 P. Buchwald-Pelcowa, Wywiad z Prof. Dr Alodia Kawecka-Gryczowa, Przegl. Bibliot., 48:1980, z. 3, s. 225-226.

15 Tamże, s. 227. 
[...] miałam to szczęście, że moja „młodość biblioteczna” upływała w kręgu wybitnych specjalistów. Na moją korzyść działały dwa ogólniejszej natury uwarunkowania: 1) obsady personalne były w ówczesnych bibliotekach stosunkowo nieliczne, 2) w bibliotekach znajdowali pracę naukowcy pierwszej rangi, którzy nie mogli zmieścić się na katedrach zaledwie paru uniwersytetów. Z reguły byli to specjaliści różnych dziedzin humanistycznych, dla których bibliotekarstwo stanowiło zawód nabyty. Może kilka nazwisk przybliży środowisko tamtych lat: socjolog Kazimierz Dobrowolski, historyk sztuki Zofia Ameisenowa, znawca literatury staropolskiej Ludwik Bernacki, historyk nauk ścisłych Aleksander Birkenmajer. (...) Młodzież oprócz umiejętności fachowych nabywała w kontaktach ze starszymi kolegami pewnej ogólnej „ogłady” umysłowej. Nie było przecież wówczas szkół dla bibliotekarzy naukowych, bardzo rzadko organizowano krótkotrwałe kursy. Nic dziwnego, że kształcenie odbywało się często systemem sokratesowskim - w czasie rozmów z mistrzem, starym obyczajem czeladniczego terminowania. Oczywiście, resztę uzupełniało się intensywną lekturą ${ }^{16}$.

Zdaniem A. Kaweckiej-Gryczowej kandydaci do pracy w działach zbiorów specjalnych powinni mieć wielopłaszczyznowe wykształcenie, zdobyte - jak już wspomniałam - nie tylko na studiach bibliotekoznawczych. Pełniąc przez całe lata różne funkcje kierownicze utwierdzała się w przekonaniu, że „prawdziwą (...) znajomość metod pracy naukowej $\mathrm{z}$ dawną książką daje dopiero dłuższe z nią współżycie" $17 \mathrm{z}$ jednej strony, a z drugiej musi być „,dobra znajomość całego tła, czyli historii i literatury staropolskiej bądź dziedzin pokrewnych" ${ }^{18}$. Jej troska o kształcenie bibliotekarzy nie przejawiała się tylko w sygnalizowaniu takiej konieczności. Czynnie brała udział w tworzeniu podwalin systemu kształcenia bibliotekarzy w Polsce.

Jeżeli chodzi o osobiste doświadczenia w pracy dydaktycznej na rzecz kształcenia kadr bibliotekarskich, to początki działań A. Kaweckiej-Gryczowej na tym polu sięgają 1945 roku. Po zakończeniu wojny, w wyniku działań wojennych i wysiłków okupanta, wiele zbiorów bibliotecznych było zdewastowanych i zdezorganizowanych. Doszły też nowe zbiory, które należało udostępnić szerokiej rzeszy czytelników. Natomiast zubożone zostało środowisko i tak niezbyt licznych fachowców, którzy mogliby podołać nowym wyzwaniom. Nowe władze biblioteczne zaczęły więc podejmować wysiłki, by przygotować do pracy z książką i czytelnikiem jako tako przyuczonych pracowników. Jedynym sposobem, dającym szybkie i wymierne efekty, jawiły się wówczas kursy, których organizato-

\footnotetext{
16 Tamże, s. 228.

17 Tamże, s. 230.

18 Tamże, s. 230.
} 
rem był Oddział Dawnej Książki. Patronował im najpierw Wydział Bibliotek w Ministerstwie Oświaty, później Naczelna Dyrekcja Bibliotek. A. Kawecka-Gryczowa wspominała:

Już we wrześniu 1945 r. odbył się pierwszy, dwutygodniowy kurs w Kórniku; miejsce było pod wieloma względami idealne: biblioteka ocalała w dobrym stanie, odizolowane od miejskiego zgiełku i atrakcji zapewniały możliwość skupionej, intensywnej pracy. Dość powiedzieć, ze zajęcia trwały od 9 do 21 godz. z dwiema niewielkimi przerwami na posiłki, co nasi słuchacze wytrzymywali z podziwu godnym poświęceniem i wytrwałością. W symbolicznych ławkach zasiedli bibliotekarze z Gniezna, Bydgoszczy, Gdańska, Włocławka, Krakowa, Torunia, Warszawy. Zamkowe wnętrza i piękna jesienna przyroda stwarzały wyjątkowy nastrój ${ }^{19}$.

Taki sam kurs powtórzono w 1948 roku w Bibliotece Jagiellońskiej, gdzie był większy zasób pomocy naukowych. W kursie uczestniczyło 20 osób a do reprezentantów miast z pierwszej edycji dołączyli bibliotekarze z Lublina, Tarnowa i Wrocławia. Wykładowcami na tych kursach były oprócz Alodii Kaweckiej-Gryczowej (zasady opracowywania starych druków) i Józefa Grycza, takie sławy jak: Aleksander Birkenmajer, Włodzimierz Budka (znakomity „papieroznawca”), Stanisława Sawicka i Helena Blumówna (ilustracja), Stanisław Bodniak, Zofia Budkowa i Adam Vetulani (nauki pomocnicze), Kazimierz Budzyk, Józef Korpała i Jan Baumgart (bibliografia) oraz osoby duchowne (typologia ksiąg kościelnych i organizacja Kościoła w Polsce). W kursach tych uczestniczyły osoby, które były w trakcie kończenia bądź miały za sobą ukończone studia $\mathrm{z}$ różnych dziedzin humanistycznych i posiadały krótszą lub dłuższą praktykę biblioteczną. Bywali też słuchacze bez podstawowego przygotowania fachowego. Alodia Kawecka-Gryczowa przyjmowała także zlecenia na wygłaszanie wykładów w Katedrze Bibliotekoznawstwa Uniwersytetu Warszawskiego. Prowadziła kursy, szkolenia i seminaria dla studentów i bibliotekarzy na terenie Biblioteki Narodowej i w Instytucie Badań Literackich PAN oraz w Bibliotece Jagiellońskiej, Bibliotece Katolickiego Uniwersytetu Lubelskiego i na Uniwersytecie Łódzkim.

Profesor Gryczowa nie miała ponoć zacięcia pedagogicznego i dydaktycznego w odniesieniu do swoich najbliższych współpracowników i podwładnych. W związku z tym, na drodze zdobywania przez nich wiedzy, stosowała zasadę „puszczania na głęboką wodę”. Jeśli ktoś jednak

\footnotetext{
19 Tamże, s. 230-231.
} 
autentycznie chciał uczyć się i doskonalić pod jej okiem, zawsze mógł liczyć na pełne uwagi wysłuchanie i odchodził ubogacony choć cząstką jej ogromnej wiedzy. Przepis na idealnego pracownika działu zbiorów specjalnych według Alodii Kaweckiej-Gryczowej był następujący:

W optymalnych warunkach kandydat powinien mieć wykształcenie humanistyczne (historyk, polonista, filolog klasyczny) z dobrą orientacją w zakresie epok starszych, dalej - ze znajomością choćby łaciny i bodaj na poziomie dawnej szkoły średniej oraz języków nowożytnych. I to jeszcze nie wszystko: powinien mieć czas na czytanie literatury fachowej oraz zamiłowanie do pracy naukowej. Jest to próg bardzo wysoki, a jednak spotkałam w swoim życiu szereg bibliotekarzy, także w młodym pokoleniu, którzy ten próg summa cum laude przekroczyli. Nie wątpię, że sytuacja będzie w przyszłości kształtowała się jeszcze korzystniej wobec tego, że coraz więcej młodzieży zdobywa wykształcenie uniwersyteckie. A potrzeby, choćby tylko w odniesieniu do starych druków, są olbrzymie ${ }^{20}$.

Chociaż działalność dydaktyczna nigdy nie była jej pierwszoplanowym obszarem aktywności, to jednak jako kolejny wyraz aktywności na tej płaszczyźnie należy uznać napisaną przez A. Kawecką-Gryczową wspólnie z mężem, i później już tylko przez nią uzupełnianą w kolejnych wydaniach, Historię książek i bibliotek w zarysie $(1959,1961,1964,1968)$, która wciąż zachowuje swoje walory poznawcze.

W 1935 roku Alodia Kawecka została żoną Józefa Grycza. On również jak jego żona pierwotnie związany był $\mathrm{z}$ inną dziedziną nauki w 1915 roku uzyskał doktorat z filologii germańskiej. Jednak swoją drogę i przyszłość zawodową i życiową związał z biblioteką i książką. Najpierw był wolontariat w Bibliotece Jagiellońskiej, dzięki któremu uzyskał podstawowe wyszkolenie bibliotekarskie, potem pięć lat pracy księgarskiej uwieńczonej nabyciem i prowadzeniem własnej księgarni w Zakopanem. W 1922 roku wrócił do Biblioteki Jagiellońskiej i już na stałe związał się z bibliotekarstwem. Zaangażowanie Józefa Grycza w zawód bibliotekarski można omawiać i ujmować w kilku płaszczyznach. Jest wśród nich także wycinek poświęcony trosce o przygotowanie do pracy z czytelnikiem i książką fachowych kadr bibliotekarskich. Troska ta znajdowała wyraz w podejmowaniu konkretnych działań. W oparciu o posiadaną już wiedzę o książce i jej odbiorcy w 1925 roku opracował i wydał Przewodnik dla korzystajacych $z$ bibliotek oraz spis dziet pomocniczych. Był to poradnik metodyczny korzystania z biblioteki ,zanim nie zostaną ustanowione na początku każdego roku szkolnego na uniwersytetach

${ }^{20}$ Tamże, s. 232. 
kursa wprowadzające do pracy w bibliotekach" ${ }^{21}$. Leżało mu więc na sercu przygotowanie czytelników przez, jak to dzisiaj nazywamy, szkolenia biblioteczne, ale by szkolić czytelników, jak już wspominałam, bibliotekarze winni być najpierw sami dobrze wykształceni.

Od 1 stycznia 1930 roku Józef Grycz został powołany do pracy na stanowisku radcy, referenta ds. bibliotek naukowych, w Ministerstwie Wyznań Religijnych i Oświecenia Publicznego. Dzięki temu miał możliwość oddziaływania na życie bibliotek i zawód bibliotekarza na obszarze całej Polski. Przygotowywał m.in. projekty rządowych aktów normatywnych dotyczące świata bibliotekarskiego. Jego staraniem rząd wydał „Rozporządzenie Rady Ministrów z dnia 11 kwietnia 1930 roku o służbie przygotowawczej i egzaminie kandydatów na stanowiska I kategorii w państwowej służbie bibliotecznej”22 oraz „Rozporządzenie Rady Ministrów z dnia 11 kwietnia 1930 roku o służbie przygotowawczej i egzaminie kandydatów na stanowiska II kategorii w państwowej służbie bibliotecznej" 23 . Nie tylko jednak z urzędu zajmował się Grycz problemem kształcenia i przygotowywania kadr bibliotecznych. Swoje ukształtowane podczas osobistych przemyśleń i oparte na osobistym doświadczeniu zawodowym poglądy w tej kwestii, zawarł w artykule umieszczonym w 1930 roku w „Przeglądzie Bibliotecznym” pt. O kursy bibliotekarskie. Jego spojrzenie na problem kształcenia bibliotekarzy było bardzo szerokie i obejmowało wszystkich pracowników w nich pracujących: od bibliotekarzy z dyplomami uniwersyteckimi po tych ze średnim wykształceniem, od pracowników bibliotek państwowych przez „osoby, które bibljotekarstwo pociąga lub które już się z pracą w bibljotekach zetknęły (nauczyciele szkół średnich, asystenci seminarjów i zakładów uniwersyteckich, bibljotekarze bibljotek klasztornych i kościelnych i t.p.)"24 po pracowników bibliotek prywatnych i praktykantów. Walczył o pozyskanie ich dla zawodu i danie im szansy na wykształcenie, jeżeli nie na kursach naukowych kończonych egzaminem, to chociażby na kursach wakacyjnych. W artykule tym Grycz poruszył kompleksowo kwestie konieczności powszechnego objęcia szkoleniem pracowników bibliotek, zawarł sugestie dotyczące doboru kadry wykładowców, zaproponował regulację kwestii finansowych z kursem związanych (wynagrodzenia wykładowców, czesne uczestników) oraz szczegółowy rozkład zajęć. W programie zawarł

\footnotetext{
${ }^{21}$ E. Kurdybacha, $W$ centrum..., s. 118.

22 Dziennik Ustaw RP, 1930, nr 36, poz. 294.

23 Tamże, poz. 295.

${ }^{24}$ J. Grycz, O kursy bibljotekarskie, Przegl. Bibliot., 4:1930, z. 2, s. 186.
} 
następujące bloki tematyczne: 1) bibliotekarstwo, 2) księgoznawstwo, 3) nauka o bibliografii, 4) nauka o bibliotekach, 5) nauka o Konstytucji. W podsumowaniu artykułu czytamy:

Tak oto mogłaby wyglądać w najogólniejszych zarysach organizacja pierwszego z natury rzeczy próbnego - kursu dla bibljotekarzy średniego typu, a prawidłowe przejście go zapewni kandydatom zdanie przepisanego egzaminu, bibljotekom zaś dostarczy kontyngentu jednolicie i racjonalnie wyszkolonych pracowników. Sprawa wymaga jednak jeszcze dyskusji i to w jak najszybszem tempie, gdyż czas nagli, a potrzeba wykształconych bibljotekarzy jest nader pilną. Trzeba koniecznie dążyć do tego, aby kurs średni mógł się rozpocząć jesienią roku 1930, kurs naukowy zaś w jesieni roku $1931^{25}$.

Grycz został też członkiem Państwowej Komisji Egzaminacyjnej. Jednak tak bardzo postulowane przez niego kursy nie doczekały się realizacji w praktyce. Odbywały się za to egzaminy państwowe. Sam zaś Grycz w 1931 roku prowadził zajęcia w Jednorocznej Szkole Bibliotekarskiej Faustyna Czerwijowskiego w Warszawie. Podczas II wojny światowej wspólnie z Adamem Łysakowskim organizował w Bibliotece Narodowej konspiracyjny kurs bibliotekarski, prowadząc jednocześnie po tajemne udostępnianie zbiorów.

1 kwietnia 1946 roku Józef Grycz roku został dyrektorem Naczelnej Dyrekcji Bibliotek i dzięki temu swoją działalnością mógł ponownie objąć całe bibliotekarstwo polskie $\mathrm{z}$ jego licznymi problemami w bibliotekach różnych sieci i szczebli. Tak bardzo leżące mu na sercu udostępnianie książek jak największemu gronu czytelników, było możliwe po wojnie, dzięki przygotowywanej przez niego także podczas okupacji ustawie bibliotecznej, którą znamy jako „Dekret o bibliotekach” z 1946 roku. Egzaminy wprowadzone przepisami z 1930 roku zostały wznowione po wojnie w 1946 roku i obowiązywały do 1948. Grycz zaś piastował stanowisko przewodniczącego Komisji Egzaminacyjnej w latach 1947-1948.

Józefowi Gryczowi bardzo zależało m.in. na ujednoliceniu przepisów dotyczących katalogowania książek. Tematem tym zajmował się od 1924 roku pisząc artykuł O polskie przepisy katalogowe, następnie wydając w 1934 roku Przepisy katalogowania w bibliotekach polskich. I. Alfabetyczny katalog druków. Sprawa stała się palącym problemem, zwłaszcza w okresie powojennym, gdy szeroko rozbudowywała się sieć bibliotek naukowych i powszechnych, a w tych ostatnich pracę podjęło wiele osób bez przygotowania. By ułatwić zawodowe życie pracowników

25 Tamże, s. 196. 
bibliotek opracował wraz z Władysławą Borkowską Skrócone przepisy katalogowania alfabetycznego (wydane w 1949 roku). W nurt działalności dydaktycznej Józefa Grycza wpisują się też trzy wykłady z zakresu dawnej książki, które wygłosił we wrześniu 1945 roku w Kórniku na kursie dla pracowników bibliotecznych, zorganizowanym i prowadzonym przez Oddział Dawnej Książki Ministerstwa Oświaty. Brał także udział w dwóch kursach, które odbyły się na zlecenie Ministerstwa w 1948 roku w Bibliotece Jagiellońskiej (ogólny w październiku i specjalny w listopadzie). W latach 1950-1951 zorganizował i prowadził kilkumiesięczne seminarium dla bibliotekarzy z Biblioteki Narodowej.

Swój szeroko zakrojony zamysł pedagogiczny Grycz realizował jednak zwłaszcza oddając się redagowaniu książek, pisaniu artykułów w prasie bibliotekarskiej i nie tylko, podręczników, z których mogliby czerpać wiedzę wszyscy adepci zawodu bibliotekarskiego. W latach 1925-26 jego artykuły i felietony o książce i bibliotece ukazywały się nawet $\mathrm{w}$ popularnej prasie niedzielnej. $\mathrm{Z}$ czasopism bibliotekarskich dla których pisał swe artykuły wymienić należy: „Silva Rerum”, „Exlibris”, „Biuletyn Biblioteki Publicznej w Warszawie”, „Bibliotekarza” i „Przegląd Biblioteczny”, którego był współtwórcą, zainicjował też i wydał pierwszy zeszyt „Pamiętnika Biblioteki Kórnickiej”. Wymieniając książki wspomnieć należy już przywoływany w tym referacie Przewodnik dla korzystajacych z bibliotek z 1925 roku, następnie Bibliotekarstwo praktyczne $w$ zarysie - pierwszy nowoczesny polski podręcznik bibliotekarski, opracowany podczas okupacji niemieckiej a wydany w 1945 roku. Razem z Władysławą Borkowską opracował również wspomniane już Skrócone przepisy katalogowania alfabetycznego, wydane w 1946 roku (wielokrotnie zresztą wznawiane i aktualizowane, także już po jego śmierci przez W. Borkowską).W jego dorobku znalazły się również Wskazówki dla prowadzacych biblioteki sądowe i prokuratorskie (1947). W nurt piśmiennictwa podręcznikowego wpisują się dalej Historia bibliotek $w$ zarysie $^{26}$ z 1949 roku, Z dziejów i techniki ksiązki ${ }^{27}$ z 1951 r. oraz wydana wspólnie z Emilią Kurdybachą w 1953 r. Bibliografia w teorii $i$ praktyce. Kolejna pozycja o charakterze podręcznikowym to skrypt z wiadomości o książce, wykorzystywany przy szkoleniu zawodowym pracowników „Domu Książki”, dalej skrypty dla Państwowego Ośrodka Kształcenia Korespondencyjnego Bibliotekarzy takie jak Biblioteka jako teren pracy bibliotekarza z 1953 roku i Krótki zarys historii książki i bibliotek z 1954 roku. Dorobek piśmienniczy Józefa Grycza dowodzi, iż żywo

${ }^{26}$ J. Grycz, Historia bibliotek w zarysie, Warszawa 1949, $96 \mathrm{s.}$

${ }^{27}$ J. Grycz, Z dziejów i techniki książki, Wrocław 1951, $271 \mathrm{~s}$. 
interesował się problemami bibliotek i pracujących w nich bibliotekarzy w odniesieniu do placówek wszystkich typów i kategorii, jakie istniały w Polsce podczas jego aktywności zawodowej.

Wielkość Józefa Grycza jako człowieka nie dbającego o własne profity i poklask dla własnego nazwiska oraz jego oddanie sprawie książek, bibliotek i zawodowi bibliotekarskiemu, ale też i jego spryt, by nie powiedzieć przebiegłość, ukazuje przywołana przez Emilię Kurdybachę, sprawa jej współautorstwa z Gryczem pracy Bibliografia w teorii i praktyce. Maszynopis tej pracy, pod tytułem Bibliografia, teoria, technika, Grycz miał ukończony już w maju 1949 roku. Jednak w tym okresie zmuszono go do odejścia ze stanowiska w Naczelnej Dyrekcji Bibliotek, a wspomnianej pracy nie zaakceptowano do druku. Emilia Kurdybacha wspomina:

W przekonaniu, że ogłoszenie Bibliografii jest pilnie potrzebne, z właściwą mu konsekwencją postanowił tekst częściowo zmienić, znacznie rozszerzyć i dodać wykaz ważniejszych bibliografii i dzieł pomocniczych. Aby tę pracę przyspieszyć, zostałam wciągnięta do wyszukiwania i przygotowania części materiału; najczęściej pomoc taka bywa kwitowana w przedmowach. U Grycza było inaczej. Każda formułowana przez niego z dostarczonego materiału myśl i strona były dyskutowane, byłam zmuszona niejako do osobistego stosunku i ,przyjęcia odpowiedzialności" tak za te strony, które opracował, jak i za te, które sama napisałam. Ileż wówczas musiałam przeczytać, wyszukać i nauczyć się. Grycz, świetnie obeznany z literaturą przedmiotu, przykładający dużą wagę do śledzenia bieżącego czasopiśmiennictwa fachowego, był bardzo wymagający. Wiele problemów niezwiązanych bezpośrednio z przygotowywaną do druku książką było również omawianych. Każdemu z młodszych kolegów życzę znalezienia takiej formy nauki ${ }^{28}$.

Podejmując próbę nakreślenia pewnych ram, obejmujących życie prywatne i zawodowe małżeństwa Gryczów, można ująć to następująco: urodzili się w Polsce podzielonej zaborami. Czas zdobywania przez nich wykształcenia oraz stawiania pierwszych kroków na ścieżce kariery zawodowej, przypadł na okres, w którym Polska odzyskała już niepodległość. Dane im było również przejść przez trudne doświadczenie II wojny światowej i okupacji, po którym w trudnych powojennych warunkach i w nowej rzeczywistości politycznej, uczestniczyli w dziele odbudowy i tworzenia instytucji związanych z upowszechnianiem i udostępnianiem książki. Tworzyli podwaliny nauki o książce i bibliotece. Mam nadzieję, iż udało mi się pokazać jak mocno leżała im na sercu kwestia kształcenia i przygotowywania do pracy z czytelnikiem wykwalifikowanych kadr bibliotecznych. Sami Gryczowie wywodzili się z pokolenia naukowców, którzy

${ }^{28}$ E. Kurdybacha, W centrum..., s. 130. 
z uwagi na brak takiej możliwości, nie mieli formalnego wykształcenia bibliotekoznawczego. Alodia Kawecka-Gryczowa ukończyła studia filologiczne (filologia polska) a Józef Grycz w 1915 roku uzyskał doktorat z filologii germańskiej. Oboje wybrali jednak i podjęli pracę w bibliotekach, angażując się w problemy dotyczące książek, ludzi pracujących z książkami na poszczególnych etapach życia tychże, oraz instytucji z książką związanych. Można powtórzyć za Barbarą Bieńkowską: „Wiedzieli, iż bibliotekarstwo jest zawodem, któremu w miarę rozwoju współczesnego społeczeństwa są i będą stawiane coraz wyższe wymagania profesjonalne. Sami doświadczyli, że na tym gruncie wykształcenie z innych dziedzin jest niewystarczające, choć bardzo pomocne. Dlatego nader aktywnie angażowali się w różne formy nauczania i doskonalenia młodszych kolegów, począwszy od szkolenia przywarsztatowego, poprzez kursy specjalistyczne aż do akademickiego kształcenia bibliotekarzy" ${ }^{29}$.

\section{Summary}

\section{Professional Training of Librarians in the Views and Practice of Alodia Kawecka-Gryczowa and Józef Grycz}

In Poland, the idea of educating library personnel at university level has its roots already during the times of the Commission of National Education in the second half of the eighteenth century. The Grycz couple themselves belonged to the generation, which due to lack of such studies, had no degrees in library science, but in other fields of knowledge. Nevertheless, the issue of educating and training librarians to work with the reader and the book was one of their chief concerns. In their eyes the library was the ideal meeting point of the reader with the book, and the librarian - methodically prepared for the job - an ideal middle person. Alodia Kawecka-Gryczowa gained her first personal experience in training librarians in 1945. Józef Grycz among other delivered lectures at librarian courses organized in the Kórnik Library in 1945, and in the Jagiellonian Library in 1948. But his chief contribution in this field, showing to the full his pedagogical concepts with relation to librarian training, came through editing books, writing articles for journals devoted to library science, and writing textbooks and manuals aimed at educating candidates for the library profession.

${ }^{29}$ B. Bieńkowska, Przedmowa, [w:] W kręgu nauki i bibliotek, (Bibliotekarze Polscy we Wspomnieniach Współczesnych, 3), Warszawa 1993, s. 6. 


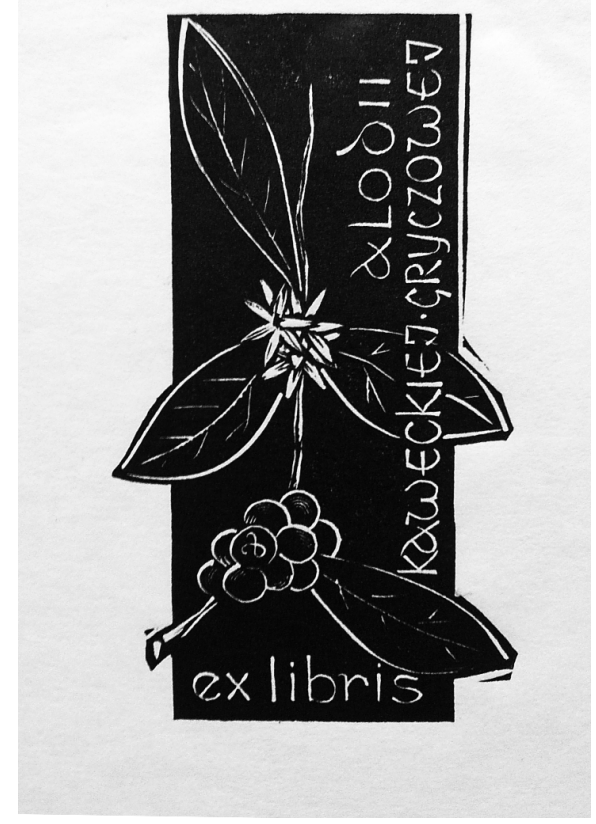

Eklibris Alodii Kaweckiej-Gryczowej

(zdjęcie ze zbiorów Biblioteki Narodowej) 